\title{
ANALISIS MARKETING MIX TERHADAP MAHASISWA BARU DALAM MEMUTUSKAN STUDI LANJUT PADA SEKOLAH TINGGI ILMU EKONOMI MANDALA JEMBER
}

\author{
Oleh: \\ Hayatul Maspufah \\ Program Studi Manajemen \\ Sekolah Tinggi Ilmu Ekonomi Mandala Jember \\ Email : \\ ulfa@STIE-mandala.ac.id
}

\begin{abstract}
ABSTRAK
Penelitian ini dimaksudkan untuk menganalisis unsur-unsur Marketing Mix yang mempengaruhi mahasiswa baru dalam memutuskan studi lanjut pada Sekolah Tinggi Ilmu Ekonomi Mandala Jember. Data yang digunakan adalah data primer, yaitu yang diperoleh dari hasil pengumpulan kuisioner terhadap mahasiswa baru STIE Mandala Jember angkatan tahun 2019. Pengambilan sampel menggunakan tehnik Proportional Random Sampling. Pengujian dilakukan terhadap tujuh variabel Marketing Mix, yang terdiri dari: Produk, Harga, Promosi, Lokasi, Personil, Proses, Bukti Fisik dengan model analisis yang digunakan adalah Regresi Linier Berganda. Hasil uji $\mathrm{F}$, menunjukkan bahwa secara simultan variabel $\mathrm{X}_{1}$ (Produk), $\mathrm{X}_{2}$ (Harga), $\mathrm{X}_{3}$ (Promosi), $\mathrm{X}_{4}$ (Lokasi), $\mathrm{X}_{5}$ (Personil), $\mathrm{X}_{6}$ (Proses) dan $\mathrm{X}_{7}$ (Bukti Fisik) berpengaruh signifikan terhadap (Y) keputusan mahasiswa studi lanjut di STIE Mandala Jember. Hasil uji t, menunjukkan bahwa masing-masing variabel $\mathrm{X}_{1}$ (Produk), variabel $\mathrm{X}_{2}$ (Harga), variabel $\mathrm{X}_{3}$ (Promosi), variabel $\mathrm{X}_{4}$ (Lokasi), dan variabel $\mathrm{X}_{7}$ (Bukti Fisik) berpengaruh secara signifikan terhadap keputusan mahasiswa studi lanjut di STIE Mandala Jember, sedangkan variabel $\mathrm{X}_{5}$ (Personil) dan variabel $\mathrm{X}_{6}$ (Proses) tidak berpengaruh secara signifikan terhadap keputusan mahasiswa studi lanjut di STIE Mandala Jember. Variabel yang berpengaruh paling dominan dari penelitian ini adalah variabel promosi.
\end{abstract}

Keyword: Keputusan, Pemasaran Jasa (Marketing Mix), Studi Lanjut

\begin{abstract}
This research is intended to find out "Marketing Mix Analysis of New Students in Deciding Further Studi at STIE Mandala Jember. The data used are primary data, which is obtained from the results of questionnaire collection for new students of STIE Mandala Jember class of 2019. Sampling used is Proportional Random Sampling technique. The test was conducted on seven Marketing Mix variables, consisting of: Product, Price, Promotion, Location, Personnel, Process, Physical Evidence with the analysis model used is Multiple Linear Regression. F test results,
\end{abstract}


shows that simultaneously variables $X_{1}$ (Product), $X_{2}$ (Price), $X_{3}$ (Promotion), $X_{4}$ (Location), $X_{5}$ (Personnel), $X_{6}$ (Process) and $X_{7}$ (Physical Evidence) have a significant effect on $(Y)$ decision of further studi students at STIE Mandala Jember. $t_{\text {test }}$ results, shows that each variable $X_{1}$ (Product), variable $X_{2}$ (Price), variable $X_{3}$ (Promotion), variable $X_{4}$ (Location), and variable $X_{7}$ (Physical Evidence) significantly influence the decision of further studi students at STIE Mandala Jember, while variable $X_{5}$ (Personnel) and variable $X_{6}$ (Process) did not significantly influence the decision of further studi students at STIE Mandala Jember. The variable that has the most dominant influence in this studi is the promotion variable.

Keyword: Advanced Studi, Decision, Marketing Mix

\section{A. PENDAHULUAN}

Program pembangunan Indonesia merupakan bagian dari upaya membangun dunia. Di dalam perkembangan itu terkandung motivasi untuk membangun citra komitmen pendidikan Tinggi yaitu mempercepat alih pengetahuan dan teknologi yang tidak bisa dilihat terlepas dari pembangunan bangsa. Pendidikan merupakan sarana yang sangat tepat menunjang perkembangan suatu negara, dimana pendidikan merupakan salah satu faktor penting dalam rangka mengembangkan sumber daya manusia.

Sektor pendidikan merupakan faktor yang terkait langsung dengan kemajuan masyarakat ke arah yang lebih baik. Tingginya pendidikan masyarakat secara langsung akan mendorong pembangunan negara menuju era perkembangan yang dicita-citakan. Kesadaran masyarakat terhadap pendidikan tinggi cenderung meningkat. Mereka menyadari bahwa untuk menghadapi tantangan masa yang akan datang salah satunya harus mempunyai pendidikan tinggi, mereka mampu mengembangkan diri untuk lebih maju. Tingginya kesadaran masyarakat menyebabkan dibutuhkannya lembaga pendidikan yang mampu menampung minat masyarakat akan pendidikan tinggi dan ilmu pengetahuan yang dapat digunakan untuk meningkatkan kualitas diri mereka (Mustari \& Rahman, 2014).

Pendidikan Tinggi harus merupakan kunci dalam mengembangkan pengetahuan dan kualitas kemampuan mahasiswa belajar untuk meraih peluang partisipasi yang akan muncul dalam transformasi dunia dan pembangunan berkelanjutan masyarakat kita. Perguruan Tinggi dengan berbagai bidang studi dan ilmu adalah organisasi penghasil produk berupa jasa harus dipasarkan kepada konsumen, atau mahasiswa. Produk dari Perguruan Tinggi adalah Tri Dharma Perguruan Tinggi yaitu Pendidikan, Penelitian dan Pengabdian kepada masyarakat. Ketiga jasa tersebut dapat diklasifikasikan sebagai pelayanan jasa yang berulang dan berdaya tahan lama. Sifat produk semacam itu akan membawa konsekuensi terhadap bentuk pelaksanaan fungsi pemasarannya, apabila Perguruan Tinggi kurang memperhatikan atau bahkan tidak melakukan fungsi pemasaran akibat yang ditanggungnya akan berlangsung lama (Mustari \& Rahman, 2014).

Dalam membentuk citra yang baik terhadap lembaga dalam rangka menarik minat mahasiswa maka lembaga pendidikan dalam hal ini Perguruan Tingggi 
Swasta dapat mengembangkan berbagai upaya berdasarkan pada konsep pemasaran, disamping fungsi utamanya sebagai lembaga pendidikan. Dengan tujuan agar konsumen atau mahasiswa mau melakukan pembelian terhadap jasa yang ditawarkan, maka mutu pendidikan harus memuaskan sesuai dengan kebutuhan.

Visi dan misi STIE Mandala Jember, akan diarahkan kepada tujuan dan sasaran berupa mempersiapkan lulusan (SDM) yang berorientasi ke masa depan, berwawasan luas, studi tepat waktu dan sesuai dengan kebutuhan pasar kerja. Banyaknya bidang studi pada Perguruan Tinggi Swasta menyebabkan timbulnya persaingan dalam merebut jumlah calon mahasiswa, dengan menyajikan fasilits dan kualitas yang baik untuk anak didiknya.

Seperti halnya dalam penelitian produk, ketika konsumen akan memilih jasa pendidikan, mereka juga dipengaruhi oleh banyak faktor. Pandangan yang dihasilkan Perguruan Tinggi baik yang berupa bentuk fisik maupun non fisik menyebabkan adanya ketidakmerataan jumlah calon mahasiswa diantara Perguruan Tinggi Swasta yang ada. Berdasarkan pemikiran tersebut penulis berkeinginan untuk mengkaji ada tidaknya pengaruh bauran pemasaran jasa terhadap keputusan mahasiswa memilih kuliah di Sekolah Tinggi Ilmu Ekonomi Mandala Jember dengan cara mengetahui pengaruh dari variabel-variabel produk, harga, lokasi, promosi, personil, proses serta bukti fisik terhadap keputusan mahasiswa memilih kuliah di Sekolah Tinggi Ilmu Ekonomi Mandala Jember dan variabel yang mempunyai pengaruh paling dominan terhadap keputusan mahasiswa memilih kulian di Sekolah Tinggi Ilmu Ekonomi Mandala Jember.

\section{B. KAJIAN PUSTAKA}

\section{Konsep Pemasaran}

Menurut Suhardi \& Pragiwani, (2017), kegiatan promosition (promosi) dapat dilakukan dengan berbagai upaya seperti iklan, presentase ke sekolahsekolah, dan mencetak brosur. People (personalia) merupakan tenaga dosen kwalifikasi pendidikan Doktor dan Magister serta karyawan yang profesional. Physical evidence yaitu penampilan gedung dan fasilitas penunjang sangat baik. Process yaitu pelaksanan proses belajar mengajar dilaksanakan dengan baik sesuai dengan pedoman yang diatur oleh pemerintah.

\section{Perguruan Tinggi Sebagai Industri Jasa}

Perguruan Tinggi sebagai lembaga pendidikan tinggi dapat dipandang sebagai suatu proses yaitu proses produksi. Sebagai proses produksi Perguruan Tinggi adalah semacam perusahaan atau industri dalam hal ini industri jasa. Sabagai suatu industri, perguruan tinggi harus dikelola menurut azas-azas ekonomi perusahaan. Perguruan Tinggi bukanlah suatu perusahaan yang senantiasa mengejar keuntungan finansial, tetapi bukan juga badan amal, melainkan sebuah industri yang paling vital yang harus dikelola seefektif dan seefisian mungkin. Oleh karena itu pengelolaannya harus memperhatikan manajemen bisnis, dalam hal ini manajemen profesional. Dilihat dari segi pertanggungjawaban sosial, manajemen 
seperti ini semakin penting, lebih-lebih jika perguruan tinggi yang bersangkutan, dalam hal keuangan banyak tergantung pada masyarakat.

\section{Faktor Bauran Pemasaran (Marketing Mix)}

Bauran pemasaran merupakan tindakan dan keputusan tertentu yang ditujukan untuk tujuan perusahaan dan memenuhi kebutuhan pelanggan. Pada zaman modern ini, perusahaan beroperasi dalam lingkungan yang terus berubah. Layanan yang dapat memenuhi kebutuhan pelanggan perlu disediakan agar berhasil dan tetap menguntungkan dalam usaha (Išoraitè, 2016). Bauran pemasaran merupakan kombinasi variabel-variabel pemasaran yang dikendalikan dan digunakan oleh perusahaan untuk mencapai tingkat penjualan yang diinginkan dalam pasar sasaran. Menurut Tjiptono, (2014) Bauran pemasaran jasa terdiri dari delapan variabel yaitu:

\section{Produk (Product)}

Suatu produk yang dihasilkan perusahaan dapat bersifat tampak (tangible)s maupun tidak tampak (intangible). Produk yang tampak disebut sebagai barang (goods) seperti furnitur; pakaian, bahan makanan dll, sedangkan produk yang tidak tampak seperti jasa (Singh, 2012). Jasa memiliki empat karakteristik yang membedakannya dari barang yaitu : (1) tidak tampak secara phisik (intangibility), (2) tidak tahan lama (perishability), (3) tidak terpisahkan dan (4) dapat berubah setiap saat (variability). Sifat ketidakmampuan jasa mengandung pengertian bahwa jasa tidak dapat diperlihatkan, diangkut, disimpan, dikemas, atau diawasi sebelum dilakukan pembelian. Disamping itu, jasa tidak dapat disimpan untuk penjualan yan akan datang (Tjiptono, 2014).

\section{Harga (Price).}

Penetapan harga harus sesuai dengan kualitas produk yang dihasilkan dan dapat memuaskan konsumen yang membelinya. Harga merupakan nilai produk yang diekspresikan dalam satuan moneter atau nilai tukar uang. Untuk menetapkan harga produk, manajemen perlu menetapkan tujuan penetapan harga itu sendiri. Pada umumnya, terdapat tiga tujuan atau orientasi utama penetapan harga yaitu: (1) orientasi keuntungan, (2) orientasi penjualan, (3) orientasi status quo. Orientasi keuntungan dilakukan perusahaan melalui target maksimalisasi keuntungan. Maksimalisasi keuntungan lebih merupakan kebijakan untuk jangka panjang, sedangkan target pengembalian biasanya ditetapkan untuk jangka pendek. Pada beberapa perusahaan perhatian penetapan harga didasarkan pada orientasi volume penjulan. Dalam situasi demikian, tujuan penetapan harga dapat diarahkan pada peningkatan volume penjualan, atau mempertahankan atau meningkatkan pangsa pasar (market share). Pangsa pasar dapat dijadikan sebagai indikator kesehatan perusahaan, ketika pasar berkembang secara menyeluruh, sedangkan pertimbangan status quo dilakukan dengan mempertahankan harga pada tingkat yang stabil dan menikuti persaingan. Stabilisasi harga dilakukan oleh perusahaan besar yang 
menjadi pemimpin pasar dengan produk yang telah distandarisasi, sedangkan perusahaan lain akan mengikutinya (Tjiptono, 2014).

\section{Promosi Pemasaran (Promotion)}

Promosi pemasaran merupakan sarana komunikasi yang digunakan untuk menginformasikan, membujuk atau mengingatkan konsumen tentang produk, citra, ide, keterlibatan masyarakat maupun dampak sosial yang dihasilkannya. Promosi pemasaran merupakan salah satu bentuk komunikasi pemasaran yang dilakukan perusahaan kepada masyarakat. Proses komunikasi dalam promosi pemasaran memiliki beberapa komponen penyampaian pesan dari pengirim kepada penerima. Perusahaan dalam mengambil keputusan pemasaran tidak lepas dari kelima komponen dalam menentukan promotional mix (bauran pemasaran), yaitu: sumber, pesan, media (vehicle), audience, dan perilaku yang diinginkan. Perusahaan menggunakan sumber daya promosi untuk mencapai tujuan yang secara khusus ditentukan sebagai perilaku yang diinginkan dari sekelompok orang, sehingga titik awal penentuan keputusan promosi adalah menentukan kelompok orang tertentu (konsumen atau organisasi) yang disebut sebagai audience. Arti penting promosi pemasaran sebagai sarana komunikasi antara perusahaan dengan audience (konsumen), adalah (1) memberikan informasi, (2) modifikasi tingkah laku, (3) membujuk, dan (4) mengingatkan. Kegiatan promosi pemasaran meliputi kegiatankegiatan untuk memberitahu pasar tentang adanya penawaran suatu produk dari perusahaan. Promosi yang bersifat informatif sangat penting bagi konsumen, karena dapat membantu dalam pengambilan keputusan untuk melakukan pembelian. Sebagian konsumen tidak akan membeli barang atau jasa sebelum mengetahi produk tersebut beserta manfaatnya (Tjiptono, 2014).

\section{Saluran Pemasaran/lokasi (Place)}

Saluran pemasaran merupakan saluran yang digunakan oleh produsen untuk menyalurkan produk tersebut dari produsen ke konsumen atau industri pemakai. Penetapan saluran distribusi menentukan lokasi cakupan pemasran produk melalui penyalur yang terdiri dari organisasi-organisasi atau orang-orang yang terlibat dalam proses pemindahan dan pertukaran produk yang dihasilkan untuk kepentingan, pemuasan keinginan konsumen. Saluran pemasaran langsung sering digunakan oleh perusahaan yang menginginkan pengendalian terhadap saluran program pemasaran, hubungan dengan konsumen yang erat, dan pasar sasaran yang terbatas. Saluran tidak langsung biasanya digunakan oleh perusahaan-perusahaan yang ingin memperluas pasar sasarannya, meningkatkan volume penjualan, mengurangi aktivitas dan biaya pemasaran, dan kemauan untuk melepaskan pengawasan dan hubungan konsumen (Tjiptono, 2014).

\section{People (Personil Traits)}

People atau Personal Traits merupakan unsur bauran pemasaran (marketing mix), yang di perguruan tinggi swasta terdiri dari pengurus yayasan, pimpinan perguruan tinggi swasta, dosen dan karyawan. Keberadaan mereka dan hubungan harmonis yang terjalin diantara mereka merupakan salah satu pengaruh bagi 
konsumen, calon mahasiswa. People juga menyangkut perilaku unsur-unsur yang ada didalam organisasi jasa tersebut. Baik buruknya perilaku pimpinan maupun bawahan dalam lembaga tersebut menentukan kualitas manajemennya. Diharapkan juga terjalin hubungan erat antara pemberi jasa dengan yang memerlukannya (Tjiptono, 2014).

\section{Proses ( Process )}

Dalam perusahaan jasa, process merupakan salah satu faktor penting dalam marketing mix, karena konsumen menganggap sistem dan prosedur pemberian jasa tersebut sebagai bagian dari jasa itu sendiri. Keputusan dan pelaksanaan manajemen operasional merupakan hal yang sangat penting dalam menunjang keberhasilan pemasaran jasa. Seperti diketahui, bahwa semua kegiatan pekerjaan adalah merupakan suatu proses. Proses tersebut meliputi mekanisme pelayanan, sistemsistem, prosedur, jadual kegiatan serta rutinitas penyampaian produk atau jasa kepada konsumen. Apabila dalam operasional pelayanan berjalan efisien, maka pemberi jasa akan memperoleh keuntungan yang lebih besar terhadap pesaing yang tidak efisien layanannya. Kejelasan terhadap peraturan, sistem-sistem prosedur yang berlaku dan kalancaran informasi akan sangat mempengaruhi persepsi konsumen terhadap kualitas jasa yang diberikan (Tjiptono, 2014).

\section{Bukti Fisik (Physical Evidence)}

Physical Evidence atau bukti fisik adalah tempat dimana produk jasa diciptakan dan antara pembeli serta konsumennya berinteraksi. Physical evidence membantu positioning dari suatu perusahaan jasa, seperti perguruan tinggi, dan memberikan dukungan yang penting pada layanan jasanya. Hal ini sangat penting dan dapat mempengaruhi persepsi konsumen atas kualitas jasa yang ditawarkan oleh pemberi jasa (Tjiptono, 2014). Physical evidence dibedakan menjadi dua jenis, yaitu:

a. Essential evidence, yaitu bagian dari sarana phisik yang tidak dapat dimiliki oleh pemakai jasa misalnya gedung, peralatan kantor dan lain-lain.

b. Peripheral evidence, yaitu bagian dari sarana phisik yang dapat dimiliki oleh pemakai jasa, misalnya buku pedoman, sertifikat, ijazah.

\section{Layanan Pelanggan (Customer Service)}

Layanan pelanggan pada pemasaran jasa lebih dilihat sebagai hasil (outcome) dari kegiatan distribusi dan logistic, dimana pelayanan diberikan kepada konsumen untuk mencapai kepuasan. Layanan pelanggan meliputi aktivitas untuk memberikan kegunaaan waktu dan tempat, termasuk pelayanan pratransaksi, saat transaksi, dan pascatransaksi. Kegiatan pratransaksi akan turut mempengaruhi kegiatan saat dan pascatransaksi. Oleh karena itu, kegiatan pendahuluannya harus dilakukan sebaik mungkin sehingga konsumen memberikan respons yang positif dan menunjukkan loyalitas yang tinggi (Rambat, 2016).

Beberapa penelitian sebelumnya berkaitan dengan Marketing Mix, berdasarkan hasil penelitian yang dilakukan oleh Sama, Marnisah, \& Hendro, 
(2017) menunjukkan bahwa secara bersama-sama ada pengaruh bauran pemasaran Product, Price, Promotion, Place, Personal traits, Process, dan Physical evidence terhadap keputusan mahasiswa dalam memilih PTS di Kota Palembang. Hasil penelitian (Gazali, 2017) menunjukkan bahwa masing-masing variabel independen secara terpisah mempunyai pengaruh yang signifikan terhadap keputusan calon mahasiswa memilih STIE Madani Balikapapan, serta variabel produk merupakan faktor yang paling berpengaruh terhadap keputusan calon mahasiswa memilih STIE Madani Balikpapan.

\section{METODE PENELITIAN}

Populasi dalam penelitian ini adalah calon mahasiswa baru Sekolah Tinggi Ilmu Ekonomi Mandala Jember, Jurusan Manajemen, Jurusan Akuntansi. Jurusan Ekonomi Pembangunan, Program Diploma III (D-3) angkatan tahun 2019. Teknik pengambilan sampel yang digunakan adalah Proportional Random Sampling sejumlah 100 orang. Metode analisis yang digunakan adalah Regresi Linier Berganda, dengan metode Full Regression untuk mengetahui pengaruh variabel bauran pemasaran jasa terhadap keputusan mahasiswa memilih perguruan tinggi swasta (STIE Mandala Jember). Pengujian hipotesis dalam penelitian ini dapat dilakukan dengan Uji statistik $\mathrm{F}$ untuk menunjukkan apakah semua variabel independen atau bebas yang dimasukkan dalam model mempunyai pengaruh secara bersama-sama terhadap variabel dependen/terikat dan uji asumsi klasik.

\section{HASIL DAN PEMBAHASAN}

\section{Hasil Uji Validitas}

Uji validitas dilakukan untuk mengetahui sampai sejauh mana suatu kuesioner yang diajukan dapat menggali data atau informasi yang diperlukan. Hasil uji validitas dinyatakan valid jika $\mathrm{r}_{\text {hitung }}$ minimal 0,3 (Ghozali, 2013). Sehingga dari 8 variabel yang diteliti yaitu produk $\left(\mathrm{X}_{1}\right)$, harga $\left(\mathrm{X}_{2}\right)$, promosi $\left(\mathrm{X}_{3}\right)$, lokasi $\left(\mathrm{X}_{4}\right)$, personil $\left(\mathrm{X}_{5}\right)$, proses $\left(\mathrm{X}_{6}\right)$, bukti fisik $\left(\mathrm{X}_{7}\right)$, dan keputusan $(\mathrm{Y})$, menunjukkan bahwa semua item pernyataan pada masing-masing variabel $\mathbf{r}_{\text {hitung }}>0,3$ dengan tingkat signifikansi di bawah 5\%, dan disimpulkan bahwa kuesioner yang digunakan untuk menggali data adalah valid sehingga dapat menggali data atau informasi yang diperlukan.

\section{Hasil Uji Reliabilitas}

Uji reliabilitas dilakukan untuk mengukur sampai sejauh mana kuesioner yang diajukan dapat memberikan hasil yang tidak berbeda dengan menggunakan rumus Cronbach Alph (Ghozali, 2013). Hasil pengujian reliabilitas kuesioner atas 8 (delapan) variabel dalam penelitian ini menunjukkan bahwa 8 (delapan) variabel mempunyai nilai Cronbach Alpha diatas 0,6 yang berarti reliabel. Jadi dapat disimpulkan semua konsep pengukur masing-masing variabel dari kuesioner yang digunakan dalam penelitian ini merupakan kuesioner yang handal. 


\section{Hasil Uji Normalitas}

Pengujian normalitas dilakukan terhadap residual regresi. Pengujian dilakukan dengan menggunakan grafik P-P Plot. Data yang normal adalah data yang membentuk titik-titik yang menyebar tidak jauh dari garis diagonal, jika nilainilai sebaran data terletak disekitar garis lurus diagonal maka persyaratan normalitas terpenuhi (Santoso, 2010). Hasil pengujian normalitas data menunjukkan adanya pola grafik yang normal dimana titik-titik berada tidak jauh dari garis diagonal, hal ini berarti bahwa model regresi tersebut sudah berdistribusi normal.

\section{Hasil Uji Multikolinearitas}

Hasil penelitian dari pengujian ditunjukkan pada collinearity statistics untuk mencari nilai VIF menunjukkan bahwa semua variabel yang digunakan sebagai prediktor model regresi menunjukkan nilai VIF yang cukup kecil, di mana semuanya berada di bawah 10 dan nilai Tollerance lebih dari 0,1 . Hal ini berarti bahwa variabel bebas yang digunakan dalam penelitian tidak menunjukkan gejala multikolinearitas, yang berarti bahwa semua variabel independen dalam penelitian ini adalah variabel yang saling independen. Berdasarkan penelitian yang dilakukan oleh Yuniarsih, Hakim, \& Sudodo, (2018) hasil VIF pada masing-masing variabel $<10$ dapat disimpulkan bahwa tidak terjadi gangguan multikolinearitas atau dengan kata lain model regresi ini terbebas dari gejala multikolinearitas.

\section{Hasil Uji Heteroskedastisitas}

Pengujian heteroskedastisitas dilakukan dengan menggunakan Scatter Plot (Ghozali, 2013). Hasil pengujian heteroskedastisitas menunjukkan tidak terdapat pola yang jelas dari titik-titik tersebut. Hal ini menunjukkan bahwa model regresi tidak memiliki gejala adanya heteroskedastisitas, yang berarti bahwa tidak ada gangguan yang berarti dalam model regresi ini.

\section{Hasil Uji Hipotesis Pertama}

Tabel 1.

Regresi Linier Berganda

Coefficients $^{\mathrm{a}}$

\begin{tabular}{|c|c|c|c|c|c|c|c|}
\hline \multirow[t]{2}{*}{ Model } & \multicolumn{2}{|c|}{$\begin{array}{c}\text { Unstandardized } \\
\text { Coefficients }\end{array}$} & \multirow{2}{*}{$\begin{array}{c}\text { Standardized } \\
\text { Coefficients } \\
\text { Beta }\end{array}$} & \multirow[t]{2}{*}{$\mathrm{t}$} & \multirow[t]{2}{*}{ Sig. } & \multicolumn{2}{|c|}{$\begin{array}{c}\text { Collinearity } \\
\text { Statistics }\end{array}$} \\
\hline & $\mathrm{B}$ & Std. Error & & & & Tolerance & VIF \\
\hline (Constant) & ,829 & ,810 & & 1,988 & ,531 & & \\
\hline Produk &, 577 & 177 & ,287 & 1,689 &, 022 & ,542 & 2,884 \\
\hline Harga & 689 & 128 &, 865 & 3,100 &, 002 & ,422 & 2,478 \\
\hline Promosi &, 875 &, 113 & ,988 & 5,882 &, 001 &, 543 & 1,442 \\
\hline Lokasi &, 766 & 166 & 677 & 1,679 &, 003 & 602 & 1,422 \\
\hline Personil & ,088 & 199 & ,088 & ,989 & ,224 & ,582 & 3,710 \\
\hline Proses & ,087 & , 189 & ,066 &, 878 &, 312 &, 555 & 1,842 \\
\hline Bukti Fisik &, 756 &, 118 & ,076 & 2,689 &, 003 &, 523 & 1,444 \\
\hline
\end{tabular}


a. Dependent Variable: Keputusan

b. Predictors: (Constant), $\mathrm{X}_{7}, \mathrm{X}_{5}, \mathrm{X}_{2}, \mathrm{X}_{6}, \mathrm{X}_{4}, \mathrm{X}_{3}, \mathrm{X}_{1}$

Sumber : Hasil Pengolahan Data Kuesioner dengan SPSS

Model persamaan regresi yang dapat dituliskan dari hasil tersebut dalam bentuk persamaan regresi Unstandardized coefficien adalah sebagai berikut:

$Y=0,829+0,577 X_{1}+0,689 X_{2}+0,875 X_{3}+0,766 X 4+0,088 X_{5}+0,087 X_{6}+0,756 X_{7}$

Berdasarkan hasil penelitian yang telah dilakukan, variabel produk mempengaruhi mahasiswa dalam memutuskan studi lanjut pada Sekolah Tinggi Ilmu Ekonomi Mandala Jember. Salah satu indikator yang mempengaruhi adalah status akreditasi institusi B serta performa alumni yang dipandang berhasil di masyarakat, sehingga pada variabel ini STIE Mandala harus memfokuskan diri untuk mempertahankan akreditasinya, hal ini sejalan dengan penelitian Ghazali, (2017) yang menyatakan bahwa variabel produk merupakan faktor yang berpengaruh terhadap keputusan calon mahasiswa memilih STIE Madani Balikpapan. Variabel kedua menunjukkan bahwa variabel harga berpengaruh terhadap keputusan mahasiswa memilih studi lanjut di STIE Mandala Jember, hal ini membuktikan variabel harga yang telah ditetapkan sebelumnya pada brosur serta adanya penjelasan terkait beasiswa, merupakan faktor yang mempengaruhi mahasiswa dalam mengambil suatu keputusan memilih studi lanjut di STIE Mandala Jember. Variabel promosi berpengaruh paling dominan terhadap keputusan mahasiswa memilih kuliah di STIE Mandala Jember, salah satu indikator yang mempengaruhi adalah promosi yang dilakukan secara continue melalui media social, hal yang serupa juga dijelaskan dalam penelitian yang dilakukan oleh Abril \& Rodriguez-cánovas, (2016) dimana harga dan promosi mempunyai peranan penting dalam menjalankan aktifitas pemasaran pada perusahaan. Variabel lokasi berpengaruh terhadap keputusan mahasiswa memilih studi lanjut di STIE Mandala Jember, indikator yang mempengaruhi adalah lokasi kampus yang tidak bising, memberikan ketenangan dalam mengikuti perkuliahan, dekat dengan pemondokan sehingga bagi mahasiswa yang berasal dari luar kota dapat memilih tempat pemondokan sesuai keiinginannya serta dekat dengan faslitas umum seperti perbankan yang sangat mendukung dan menjadi pilihan mahasiswa. Penelitian ini menunjukkan hasil yang berbeda dengan penelitian yang pernah dilakukan oleh Gultom, Ginting, \& Sembiring, (2014) dimana penelitiannya menyatakan bahwa secara parsial tempat tidak berpengaruh signifikan terhadap kepuasan mahasiswa. Variabel personil dan proses tidak berpengaruh secara signifikan terhadap keputusan memilih kuliah di STIE Mandala Jember, mahasiswa kurang memperdulikan terhadap indikator yang mewakili kedua variabel tersebut. Variabel bukti fisik berpengaruh terhadap keputusan Mahasiswa memilih studi lanjut di STIE Mandala Jember, indikator yang mempengaruhinya adalah STIE Mandala Jember memiliki fasiliatas gedung yang megah serta memberikan kemudahan dan kenyamanan, memiliki tempat parkir yang aman dan memadai serta lingkungan kampus yang indah dan bersih, oleh karena itu STIE Mandala Jember harus mempertahankan variabel bukti fisik tersebut dan lebih fokus dalam meningkatkan 
aktifitas yang berhubungan dengan variabel ini. Dari hasil pembahasan diatas selaras dengan hasil penelitian Sefudin, (2014) yang menyatakan konsep pemasaran masyarakat menegaskan bahwa tugas organisasi adalah menentukan kebutuhan, keinginan, dan minat dari pasar sasaran dan memberikan kepuasan yang diinginkan secara lebih efektif dan efisien dibanding pesaing dengan tetap memelihara atau meningkatkan kesejahteraan masyarakat dan konsumen.

\section{Hasil Uji Hipotesis Kedua}

Tabel 2.

Uji F (Uji Simultan)

ANOVA $^{\mathbf{a}}$

\begin{tabular}{llccccc}
\hline & Model & Sum of Squares & df & Mean Square & $\mathrm{F}$ & Sig. \\
\hline & Regression & 17,884 & 7 & 2,555 & $23,685,001^{\mathrm{b}}$ \\
1 & Residual & 4,922 & 72 &, 068 & & \\
\cline { 2 - 6 } & Total & 22,806 & 79 & & & \\
\hline c. & Dependent Variable: Keputusan \\
d. & Predictors: (Constant), $\mathrm{X}_{7}, \mathrm{X}_{5}, \mathrm{X}_{2}, \mathrm{X}_{6}, \mathrm{X}_{4}, \mathrm{X}_{3}, \mathrm{X}_{1}$ &
\end{tabular}

Sumber: Hasil Pengolahan Data Kuesioner dengan SPSS

Dari hasil pengujian hipotesis diterima dan disimpulkan terdapat pengaruh (Secara Simultan ) produk, harga, promosi, lokasi, personil, proses dan bukti fisik terhadap keputusan mahasiswa memilih studi lanjut di STIE Mandala Jember.

\section{Koefisien Determinasi}

Tabel 3.

Koefisien Determinasi

Model Summary ${ }^{b}$

\begin{tabular}{lcccc}
\hline Model & $\mathrm{R}$ & R Square & Adjusted $\mathrm{R}_{\text {Square }}$ & Std. Error of the Estimate \\
\hline 1 &, $822^{\mathrm{a}}$ &, 782 &, 712 &, 3325 \\
\hline
\end{tabular}

a. Predictors: (Constant), Bukti Fisik, Proses, Personil, Lokasi,Promosi, Harga, Produk.

b. Dependent Variable: Keputusan

Sumber : Hasil Pengolahan Data Kuesioner dengan SPSS

Koefisien determinasi ( $\mathrm{R}_{\text {Square }}$ ) yang diperoleh sebesar 0,782 . Hal ini berarti $78 \%$ keputusan mahasiswa dapat dijelaskan oleh variabel produk, harga, promosi, lokasi, pesonil, proses, dan bukti fisik. Sedangkan sisanya yaitu 22\% keputusan mahasiswa memilih studi lanjut dipengaruhi oleh variabel-variabel lainnya yang tidak diteliti dalam penelitian ini.

\section{E. SIMPULAN}

Penelitian ini membuktikan bahwa secara parsial masing-masing variabel marketing mix, produk, harga, promosi, lokasi serta bukti fisik berpengaruh signifikan (secara nyata) terhadap keputusan mahasiswa untuk studi lanjut di STIE Mandala Jember, secara parsial masing-masing variabel marketing mix personil dan proses tidak berpengaruh signifikan (secara nyata) terhadap keputusan mahasiswa untuk studi lanjut di STIE Mandala Jember. Variabel marketing mix yang 
berpengaruh paling dominan dari penelitian ini adalah variabel promosi. Penelitian ini juga membuktikan bahwa secara simultan/bersama-sama variabel marketing mix produk, harga, promosi, lokasi, personil, proses serta bukti fisik berpengaruh signifikan (secara nyata) terhadap keputusan mahasiswa untuk studi lanjut di STIE Mandala Jember. 


\section{DAFTAR PUSTAKA}

Abril, C., \& Rodriguez-cánovas, B. (2016). Marketing mix effects on private labels brand equity. European Journal of Management and Business Economics, 25(3), 168-175. https://doi.org/10.1016/j.redeen.2016.09.003

Gazali, S. (2017). ANALISIS PENGARUH BAURAN PEMASARAN JASA TERHADAP KEPUTUSAN MAHASISWA DALAM MEMILIH SEKOLAH TINGGI ILMU EKONOMI MADANI BALIKPAPAN. Jurnal Akuntansi Manajemen Madani, 1(3), 83-95. http://ejamm.stiemadani.ac.id/FILE/20171115071434Jurnal 6 online baru.pdf

Ghozali, I. (2013). Aplikasi Analisis Multivariate dengan Program SPSS. Badan Penerbit Universitas Diponegoro.

Gultom, D. K., Ginting, P., \& Sembiring, B. K. (2014). PENGARUH BAURAN PEMASARAN JASA DAN KUALITAS PELAYANAN TERHADAP KEPUASAN MAHASISWA PROGRAM STUDI MANAJEMEN FAKULTAS EKONOMI UNIVERSITAS MUHAMMADIYAH SUMATERA UTARA. JURNAL MANAJEMEN \& BISNIS, 14(1), 21-37.

Išoraite, M. (2016). Marketing mix theoretical aspects. International Journal of Research - GRANTHAALAYAH, 4(6), 25-37. https://doi.org/10.5281/zenodo.56533

Mustari, M., \& Rahman, M. T. (2014). Manajemen Pendidikan. Raja Grafika Persada.

Priyatno, D. (2010). Teknik Mudah dan Cepat Melakukan Analisa Data Penelitian dengan SPSS. Gava Media.

Rambat, L. (2016). Manajemen Pemasaran Jasa Berbasis Kompetensi. Salemba Empat.

Sama, Marnisah, L., \& Hendro, O. (2017). Bauran Pemasaran Terhadap Keputusan ahasiswa Memilih Perguruan Tinggi Swasta di kota Palembang. Jurnal Manajemen Dan Bisnis Sriwijaya.

Santoso, S. (2010). SPPS Mengolah Data Statistik Secara Profesional. Elox Media Komputindo.

Sefudin, A. (2014). REDEFINISI BAURAN PEMASARAN (MARKETING MIX) "4P" KE “4C." Journal of Applied Business and Economics, 1(1), 17-26.

Singh, M. (2012). Marketing Mix of 4P' $\mathrm{S}$ for Competitive Advantage. IOSR Journal of Business and Management (IOSRJBM), 3(6), 40-45.

Sugiyono. (2012). Metode Penelitian Kuantitatif Kualitatif dan $R \& B$. Alfabeta.

Suhardi, Y., \& Pragiwani, M. (2017). ANALISA FAKTOR-FAKTOR YANG MEMPENGARUHI KEPUTUSAN MAHASISWA MEMILIH KULIAH DI SEKOLAH TINGGI ILMU EKONOMI INDONESIA (STEI) JAKARTA. Jurnal STEI Ekonomi, 26(2), 230-247. 
Tjiptono, F. (2014). Pemasaran Jasa. ANDI.

Yuniarsih, A., Hakim, L., \& Sudodo, Y. (2018). ANALISIS PENGARUH BAURAN PEMASARAN JASA TERHADAP KEPUTUSAN SISWA MEMILIH SMK NEGERI 1 SUMBAWA BESAR (STUDI KASUS ANGKATAN 2017/2018). Jurnal Ekonomi Dan Bisnis Indonesia, 3(2). https://doi.org/https://doi.org/10.37673/jebi.v3i2.35 